\title{
Atlantis
}

Critical Studies in Gender, Culture \& Social Justice

Études critiques sur le genre, la culture, et la justice

\section{Being After Being Has Washed Away}

\section{Daze Jefferies}

Volume 41, Number 1, 2020

URI: https://id.erudit.org/iderudit/1074024ar

DOI: https://doi.org/10.7202/1074024ar

See table of contents

Publisher(s)

Mount Saint Vincent University

ISSN

1715-0698 (digital)

Explore this journal

Cite this document

Jefferies, D. (2020). Being After Being Has Washed Away. Atlantis, 41(1),

127-128. https://doi.org/10.7202/1074024ar

\section{Article abstract}

Thinking with an assemblage of Black, Indigenous, crip, decolonial, and trans feminist creative and theoretical work, this poem explores fishy felt knowledges of sex work, outmigration, colonial erasure, and archival absence in the lives of trans women from Ktaqamkuk/Newfoundland.
All Rights Reserved (C) Daze Jefferies, 2020

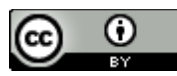

This document is protected by copyright law. Use of the services of Erudit (including reproduction) is subject to its terms and conditions, which can be viewed online.

https://apropos.erudit.org/en/users/policy-on-use/
This article is disseminated and preserved by Érudit.

Érudit is a non-profit inter-university consortium of the Université de Montréal, Université Laval, and the Université du Québec à Montréal. Its mission is to promote and disseminate research.

https://www.erudit.org/en/ 


\title{
Literary Work
}

\section{Being After Being Has Washed Away}

\author{
by Daze Jefferies
}

will this ocean and its wave theory ever forgive us?

like any poet $\mathrm{i}$ have no anchored answers, only longings / and dreams of blue-green prisms that spin upon the surface as a precious address / floating for an era in our palimpsestic water-world / like sissyfish sharing a future-present-past / to begin and end with our encounter / i open my grey eyes and feel the hit of time form a language with my skin / when being after being has washed away / we are troubled by the ghosts of all the ruptured hope that ripples through our systemic nowhere / only in ruins and always an absence - you ask me to determine how i might keep resisting if i'm never all the way here, an overflowing body / wailing for the closeness of another holy soul / thank you, master mariner, for helping me emerge from the drone drone drone of sexual labour / blowing up my phone and taking every part of me / all my sisters left to make it on their own now / shucking the flesh, we refuse response-ability / forgetting unknown holders of outmigration's touch / who rise from the seaways of the southwest shore / feeding on dulse and lovelorn liquids / a hundred queer lovers with no mother before them / staying in the wake of your hyphenated kin-ship / disposabledesirable, too much to hold dear 


\section{Formative Texts and Further Reading}

Alexander, M. Jacqui. 2006. Pedagogies of Crossing: Meditations on Feminism, Sexual Politics, Memory, and the Sacred. Durham and London: Duke University Press.

Brand, Dionne. 1997. Land to Light On. Toronto: McClelland \& Stewart.

Brathwaite, Kamau. 2000. "New Gods of the Middle Passages." Caribbean Quarterly 46 (3-4): 12-58. DOI: $10.1080 / 00086495.2000 .11672123$.

Hartman, Saidiya. 2008. "Venus in Two Acts." Small Axe: A Caribbean Journal of Criticism 12 (2): 114. DOI: $10.1215 /-12-2-1$.

Hayward, Eva and Che Gossett. 2017. "Impossibility of That." Angelaki: Journal of the Theoretical Humanities 22 (2): 15-24. DOI: 10.1080/0969725X.2017.1322814.

Jefferies, Daze. 2020. "Seawater/C-cup: Fishy Trans Embodiments and Geographies of Sex Work in Newfoundland." Imaginations: Journal of Cross-Cultural Image Studies 11 (1): 17-35. DOI: 10.17742/ IMAGE.BR.11.1.2.

Santana, Dora. 2017. "Transitionings and Returnings: Experiments with the Poetics of Transatlantic Water.” TSQ: Transgender Studies Quarterly 4 (2): 181-90. DOI: 10.1215/23289252-3814973.

Sharpe, Christina. 2016. In the Wake: On Blackness and Being. Durham and London: Duke University Press.

Daze Jefferies is a multidisciplinary artist-poet-researcher from Beothuk territory in the Bay of Exploits who holds a Master of Gender Studies from Memorial University. She is co-author of Autoethnography and Feminist Theory at the Water's Edge: Unsettled Islands (2018), and she has recent or forthcoming publications in Transgender Sex Work and Society (2018), Imaginations: Journal of CrossCultural Image Studies (2020), Riddle Fence: A Journal of Arts \& Culture (2020), Journal of Folklore Research (2021), and The Goose: A Journal of Arts, Environment, and Culture in Canada (2021), among others. Her forthcoming poetry collection, We Hold a Body of Water Together, explores hidden histories and fishy futures of trans women and sex workers in Atlantic Canada.

Abstract: Thinking with an assemblage of Black Atlantic and trans feminist creative and theoretical work, this poem explores fishy felt knowledges of sex work, outmigration, colonial erasure, and archival absence in the lives of trans women from Ktaqamkuk/Newfoundland. 